\title{
TECHNICAL AND CARTOGRAPHY STUDY OF DELIMITATION MANAGEMENT LIMITS AREA OF THE SEA CENTRAL SULAWESI PROVINCE AND NORTH MALUKU
}

\author{
Agung Kurniawan* \\ Submitted: June 25, 2019 Accepted: July 10, 2019
}

\begin{abstract}
As one of the countries that have a regional autonomy policy, Indonesia gives authority to regional governments to implement and manage the wealth of natural resources in the region, including the potential and wealth of marine resources. The basic juridical area in carrying out natural resource management which is the authority of the regions is set out in Law No. 23 of 2014 which is a revision of the previous Law, namely Law No. 32 of 2004. Local governments have the right to conduct the management of marine resources with an area of 12 miles drawn from the position of the baseline towards the Indonesian archipelago waters. One segment of the sea area management boundary that needs to be resolved is in the Maluku sea region, namely Central Sulawesi Province and North Maluku. This study aims to provide an alternative sea level management line between Central Sulawesi and North Maluku Provinces. The method used to produce the boundaries of marine management areas is the Equidistance Principles method (equal distance) using the basepoint to basepoint. The results show that the lines produced through the boundary withdrawal process using the basepoint to basepoint approach look different when compared to the sea boundary lines that are on the national marine environment map
\end{abstract}

Keywords: Limits Area of The Sea, Delimitation, Basepoint to basepoint, Equidistance Principles

\section{INTRODUCTION}

Data from the Geospatial Information Agency states that Indonesia is an archipelagic country that has a larger ocean area than its land area. Based on data obtained from the Geospatial Information Agency (BIG), Indonesia is the largest archipelagic country in the world with 13,466 islands, $1,922,570$ $\mathrm{km} 2$ of land area and 3,257,483 $\mathrm{km} 2$ of water area (Khomsin \& Simatupang, 2016).

Indonesia as a country that adheres to the policy of regional autonomy as confirmed by Law No. 32 of 2004. One of the articles in the Law states that the authority to manage resources in the sea area can be maximally utilized by the provincial government at the most 12 miles The sea is measured from the baseline towards the high seas and/or towards the archipelagic waters and one third of the area is used for the regency/city marine authority area (Adnyana, Arsana, \& Sumaryo, 2009). Clear boundary setting is a step to optimize the utilization of existing marine resources in an area. In relation to regional boundary issues, there is still much uncertainty regarding regional administrative boundaries, especially sea boundaries, which can be seen in the fact that the inter-regional sea area is still not clear and defined on the basic map that is widely used today (Khomsin \& Simatupang, 2016).

Corresponding author:

Agung Kurniawan

Departemen Teknologi Kebumian, Sekolah Vokasi, Universitas Gajah Mada

Email: agung.kurniawan.16@mail.ugm.ac.id
Regional governments by Law number 23 of 2014 (renewal of Law No. 32 of 2004) have the authority to utilize and manage natural resources, including marine / marine resources in the regime of its territorial sea (12 miles).

One important segment of the marine management area to be immediately emphasized is the Maluku Sea region which separates two provinces, namely Central Sulawesi Province and North Maluku Province. The big challenge that is a factor in the difficulty of determining the sea boundary in the area is the large distribution of small island islands that can influence the resulting boundaries.

\section{MATERIALS AND METHODS}

The method of withdrawal of the marine area management boundary used in this study is the Equidistance Principles method (equal distance). According to the Geneva Conference in 1958, the equidistance line is the line where the dots meet with the same distance the result of withdrawal through the coastline (or baseline) as a reference for making a territorial sea withdrawal (Arsana, 2007).

The approach used in the same distance drawing in the Equidistance Principles method is to use the basepoint to basepoint approach, an approach to determining sea area boundaries measured from the baseline of each country (Supriyanto, 2010). Basepoint to basepoint approach is Withdrawal of maritime boundaries by using an equidistant 2 point basepoint method performed by drawing a line median line made from 2 basic points of both areas 
with a low water line or the base point of the two regions (Supriyanto, 2010). (illustrated in figure 1).

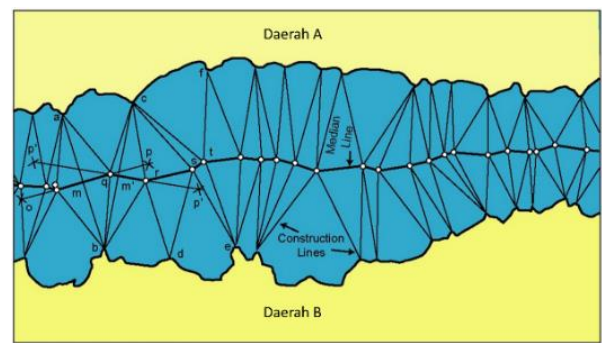

Figure 1. Illustration of median line withdrawal on Basepoint to Basepoint approach. (TALOS 2006).

Determination of the base point is carried out in accordance with the instructions at regulation of the minister of internal affairs of the Republic of Indonesia No. 141 of 2017, where the base point is the intersection of the highest tide line with land as a reference for drawing a coastline to measure the boundary of the sea drawn perpendicular to the coastline for a maximum of 12 nautical miles towards the Sea of Lepa and / or towards the Islands of the Waters for the Province (illustrated in figure 2).

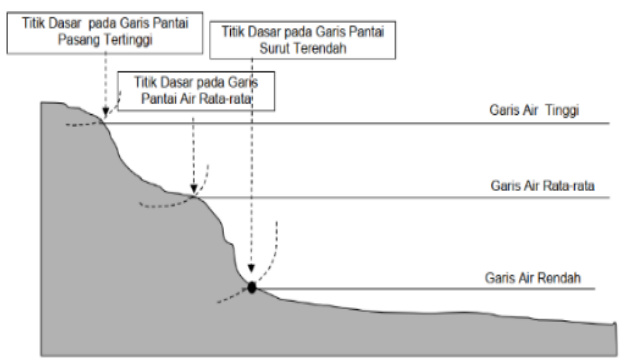

Figure 2. Illustration of determining base points (regulation of the minister of internal affairs of the Republic of Indonesia No. 141 of 2017).

The basic data used in this study is the National Marine Environment Map (Lingkungan Laut Nasional / LLN) with number sheets 24, 29, and 30, which all cover the Maluku Sea. National Marine Environment Maps are selected based on the geospatial information law which states that LLN maps are basic maps used for marine needs.

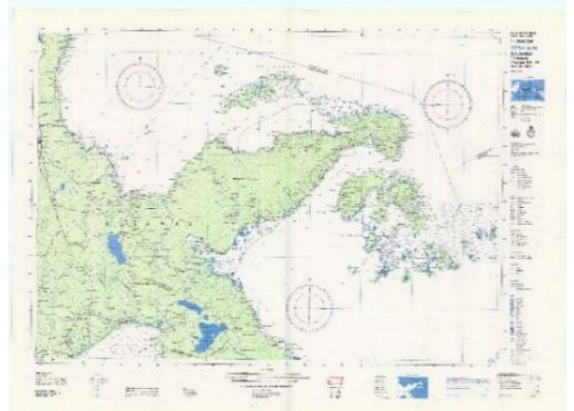

Figure 3. National Marine Environment Map number 24.

\section{Map Registration}

The map obtained is a printed map of the scanning results so that it does not have a geographic reference. The requirement for delimiting the boundaries of the marine management area is that the basic data used must have a geographical reference. Registration is done using the 1st order polynomial transformation method with RMS Error 0.0007 and UTM (Universe Transverse Mercator) coordinate system. The registration map is then overlaid with another map to produce a map mosaic.

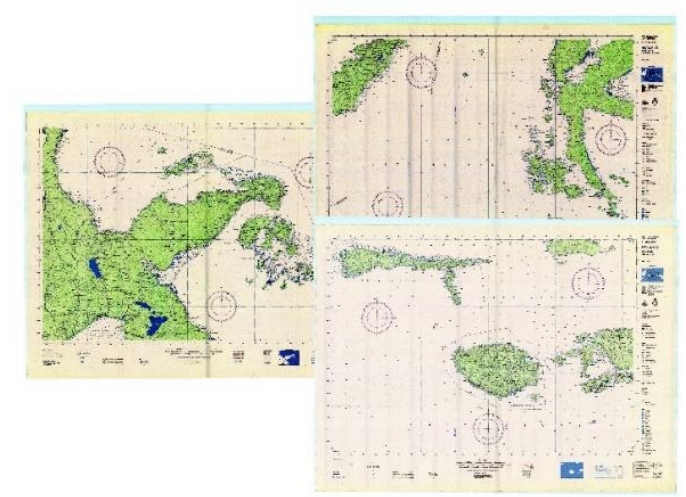

Figure 4. Mosaic map of the LLN.

\section{Base Point Determination}

The base point is determined by referring to the LLN map, which is the coordinate point on the intersection of the highest tide line, or which is often used as a coastline reference on the map. Figure 5 illustrates the basic point taking. On a small scale map, (> 1: 100,000) base point retrieval is aligned with the coastline. Figure 4 is a technical illustration of how the base point is determined.

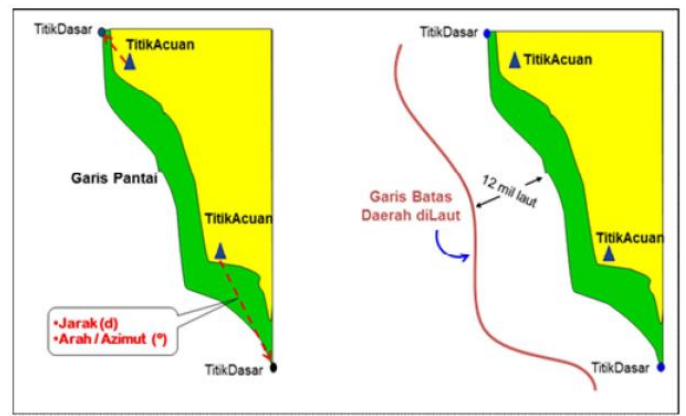

Figure 5. Technical baseline determination (regulation of the minister of internal affairs of the Republic of Indonesia No. 141 of 2017).

\section{Software}

The use of geographic information system software (GIS) in carrying out maritime boundary delimitation has an important role for median line withdrawal. The software used is geocap maritime delimitation plugin software. The plugin can calculate the equidistance line with 


\section{RESULTS AND DISCUSSION}

Base points were obtained through digitization points on the National Marine Environment map to become the basis for the regional baseline withdrawal, namely North Maluku Province in Taliabu Island and small islands around it. Figure 6 is the distribution of the base points around Taliabu Island and the surrounding small islands which are connected to the baseline. The basic points produced through the digitization process are 36 points.

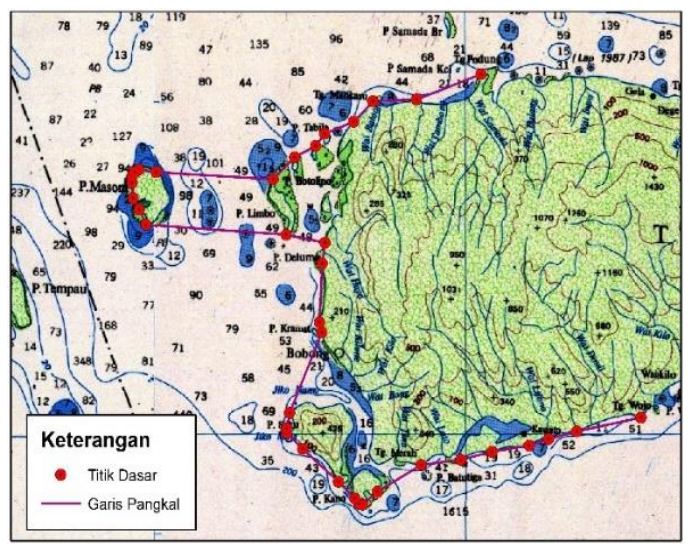

Figure 6. Digitized base point distribution map in the North Maluku region.

The basic point digitization process was also carried out to obtain basic points in the Central Sulawesi Province, namely around Lelang Island, Tanalan Island, Loisa Island, Buangbuang Island, Bokan Island, Belangan Island and Bangai Island. The base points obtained are 26 points, which are connected to produce baselines that will be used as the basis for drawing the median line. The number of base points obtained is influenced by the morphological configuration of the coast of an area. Figure 7 is a distribution map of the base points in the Central Sulawesi Province region obtained from digitization.

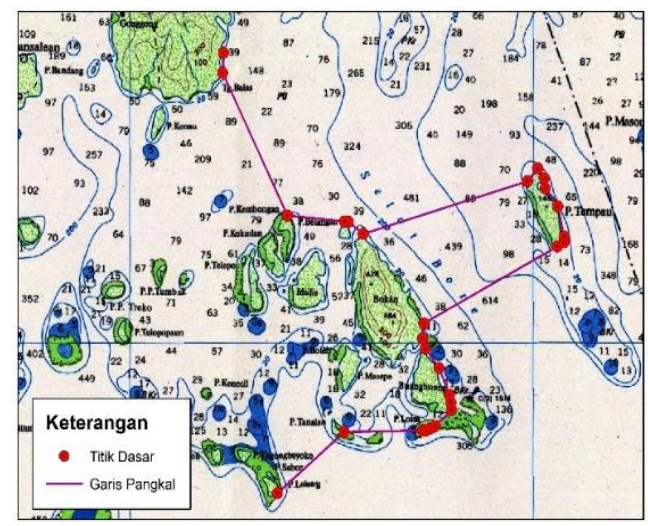

Figure 7. Distribution of basic points of digitization in the Central Sulawesi region.

Both baselines are generated through connectivity between base point; the maximum claim withdrawal is 12 nautical miles. Withdrawal of claims of a maximum of 12 nautical miles is intended to determine the claim area of the two overlapping areas. The maximum claim area of the two overlapping countries is presented in Figure 8.

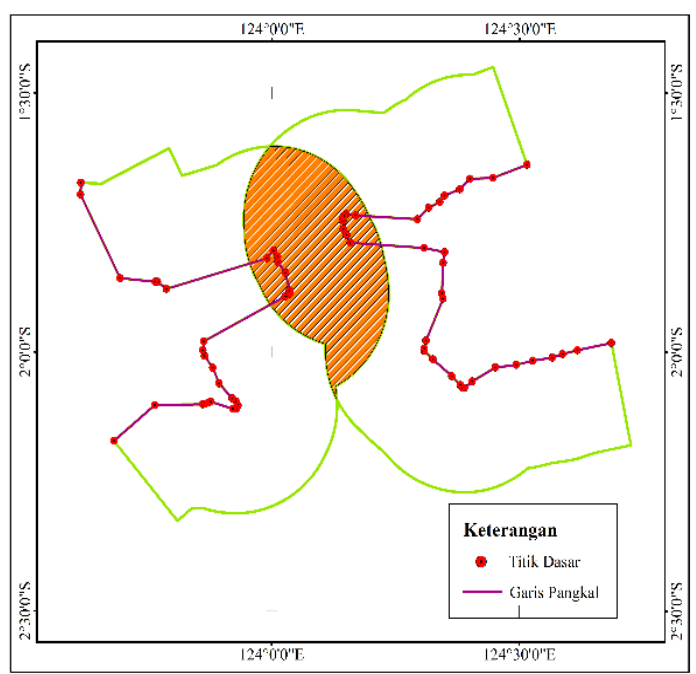

Figure 8. Visualization of overlapping claims of a maximum of 12 nautical miles.

The overlapping area is about $1096,044 \mathrm{~km} 2$. The overlapping competitiveness area is carried out by the automation of delimitation to produce the median line using the principle of the circle (see figure 9).

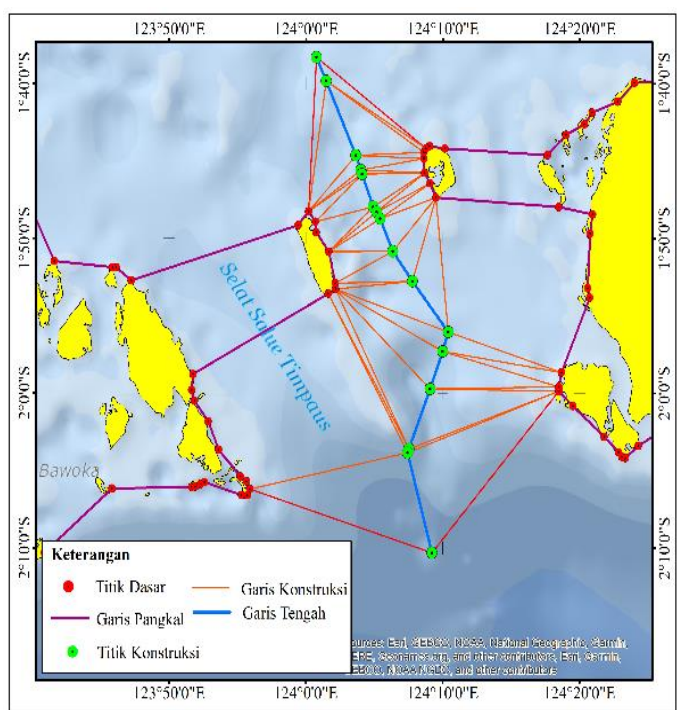

Figure 9. Construction of median line result

The construction of the circle starts from the northern end of the region which reaches to the south, to produce a midline that divides the two regions that overlap each other fairly. This line will later be used as an alternative boundary line. Figure 10 is an alternative map of the marine management boundary obtained by drawing boundary lines using the principle of equal distance method with a basepoint to basepoint approach. 


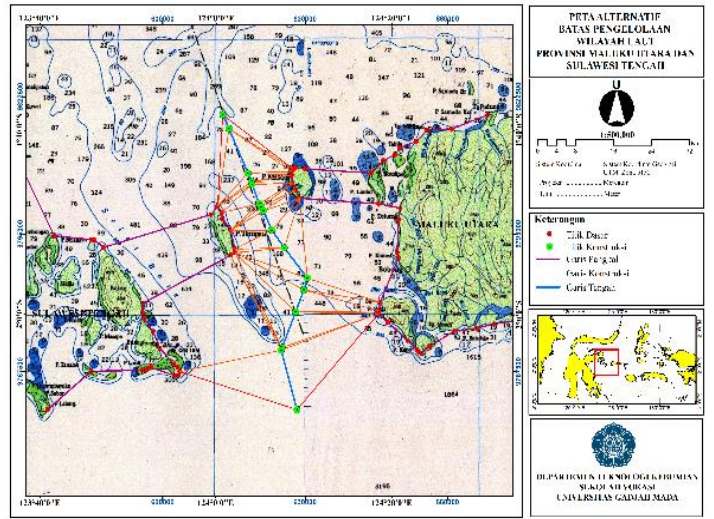

Figure 10 . The marine area management boundary map results from the calculation of the same distance principle use the basepoint to basepoint approach

Differences in sea boundary lines between sea boundaries found on LLN maps with delimitation boundary lines can be caused by several factors, including differences in baseline interpretation used, differences in GIS software used (because it will have different geometry calculations) and Differences the approach or method used. Figure 11 is a borderline difference produced by the delimitation process using the equal distance principle with the basepoint to basepoint approach compared to the boundary line on the LLN map.

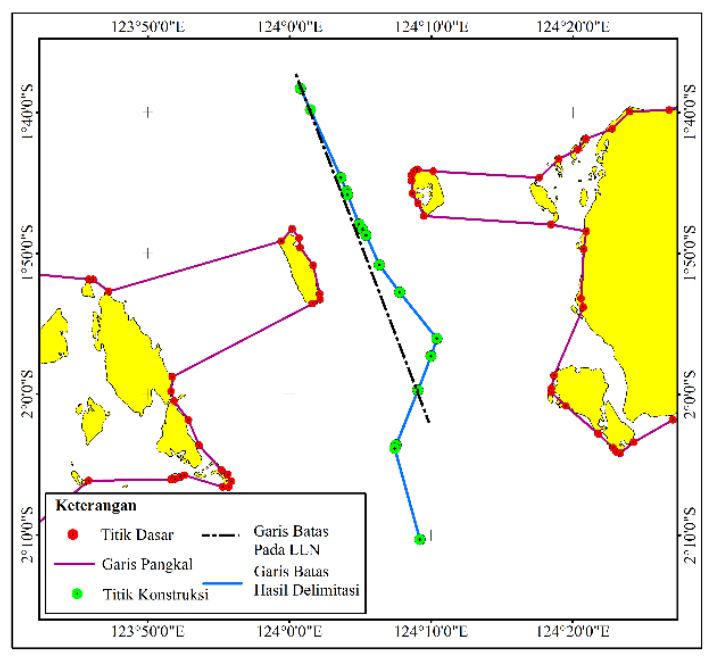

Figure 11. comparison of boundary lines on LLN maps (black) and delimitation lines (blue)

\section{CONCLUSION}

Alternative boundary lines obtained through delimitation using the equidistance principle with the basepoint to basepoint approach show different results from the sea boundary lines on the LLN map. The alternative boundaries produced do not form a straight line as in the LLN map but form an angle that adjusts to the shape of the baseline of the two regions.

\section{ACKNOWLEDGMENT}

Thank you to the GEOCAP AS for authorizing the use of geocap maritime delimitation to complete this research.

\section{REFERENCES}

Adnyana, I. G., Arsana, I. M., \& Sumaryo. (2009). Delimitasi Batas Maritim Antara Provinsi Bali dan Provinsi Nusa Tenggara Barat : Sebuah Kajian Teknis. Revitalisasi Data dan Informasi Keruangan (Geospasial) Untuk Meningkatkan Efisiensi Pengelolaan Potensi Sumberdaya Daerah. Yogyakarta: Fakultas Teknik UGM.

Arsana, I. M. (2007). Batas Maritim Antar Negara : Sebuah Tinjauan Teknis dan Yuridis. Yogyakarta: Gadjah Mada University Press.

Badan Informasi Geospasial. (1993). Peta Lingkungan Laut Nasional. Cibinong: BIG.

International Hydrographic Bureau. (2006). TALOS: A Manual on Technical Aspects Of The United Nations on The Law of The Sea - 1982. Monaco: International Hydrographic Bureau.

Khomsin, \& Simatupang, R. S. (2016). Penentuan Batas Pengelolaan Wilayah Laut Daerah Antara Provinsi Jawa Timur dan Provinsi Bali Berdasarkan Undang - Undang Republik Indonesia Nomor 23 Tahun 2014. Jurnal Geoid Volume 12 No 1, 8388.

Supriyanto, S. (2010). Problematika Batas Maritim Indonesia ditinjau dari Aspek Teknis dan Hukum. Simposium Nasional "Problematika Batas-batas NKRI ditinjau dari Aspek Teknis dan Hukum. Surabaya: Institut Teknologi Surabaya/ Markas Besar Angkatan Laut, Dinas Hidrografi dan Oseanografi. 